\title{
Catalysts as Prevailing Parties under the Equal Access to Justice Act
}

\author{
Macon Dandridge Miller $\uparrow$
}

Many federal statutes provide for the recovery of reasonable attorney's fees by a "prevailing party." Until recently, courts had interpreted prevailing party to include those who brought about a voluntary change in the defendant's conduct even though they did not obtain judicially sanctioned relief. Recovery was allowed under this socalled catalyst theory because the party had achieved its desired result in the lawsuit. ${ }^{2}$

The Supreme Court, however, rejected this definition of prevailing party for the purposes of recovery under the Americans with Disabilities Act of 1990 ("ADA") ${ }^{3}$ and the Fair Housing Amendments Act of 1988 ("FHAA") in Buckhannon Board and Care Home, Inc v West Virginia Department of Health and Human Resources. The Court held that a party that merely serves as a catalyst does not qualify as a prevailing party under these statutes. ${ }^{6}$ By rejecting the definition of prevailing party on which a majority of circuit courts had settled, the Court severely limited a party's ability to recover attorney's fees.

The narrower definition of prevailing party embraced by the Buckhannon Court has serious implications, particularly concerning civil rights and the possibility of its extension to other federal statutes, such as the Equal Access to Justice Act ("EAJA"). This Comment ex-

$\dagger \quad$ B.A. 1997, Vanderbilt University; J.D. Candidate 2003, The University of Chicago.

1 See, for example, Civil Rights Act of 1964, Pub L No 88-352, 78 Stat 259, codified at 42 USC $\S 2000$ e-5(k) (1994); Civil Rights Attorney's Fees Awards Act of 1976, Pub L No 94-559, 90 Stat 2641, codified at 42 USC $\S 1988$ (b) (1994 \& Supp 2000); Equal Access to Justice Act, Pub L No 96-481, 94 Stat 2325 (1980), codified at 5 USC § 504, 28 USC $\$ 2412$ (1994 \& 1998 Supp); 66 Stat 813 (1952), codified at 35 USC $\$ 285$ (1994):

2 See, for example, Stanton v Southern Berkshire Regional School District, 197 F3d 574, 577 (1st Cir 1999) (interpreting prevailing party to include catalysts); Marbley v Bane, 57 F3d 224, 234 (2d Cir 1995) (recognizing the catalyst theory as a viable form of recovery as a prevailing party); Baumgartner v Harrisburg Housing Authority, 21 F3d 541, 551 (3d Cir 1994) (holding that "there is no legal impediment to application of the 'catalyst theory' to show that plaintiffs were 'prevailing parties' notwithstanding the absence of a judgment or consent decree"); Environmental Defense Fund, Inc. v EPA, 716 F2d 915, 919 (DC Cir 1983) (holding that a party can achieve prevailing party status without having received a final judgment in its favor).

3 Pub L No 101-336, 104 Stat 327, codified at 42 USC \$ 12101 et seq (1994).

4 Pub L No 100-430, 102 Stat 1619, codified at 42 USC $\$ 3601$ et seq (1994).

5532 US $598(2001)$.

6 Id at 610.

7 Pub L 96-481, 94 Stat 2325 (1980), codified at 5 USC § 504, 28 USC § 2412 (1994 \& Supp 
amines whether the holding of Buckhannon applies to the EAJA. While the Supreme Court clearly disapproved of the catalyst theory for the statutes at issue in Buckhannon, it did not specifically discuss the applicability of its decision to the EAJA. Lower courts addressing Buckhannon's application to the EAJA have reached different conclusions. ${ }^{8}$ Upon analysis of the relevant considerations, this Comment ultimately determines that the catalyst theory continues to be a valid means of achieving prevailing party status under the EAJA.

Part I begins by introducing fee-shifting statutes and outlining the specific fee-shifting provisions of the EAJA. This Part continues with a discussion of pre-Buckhannon recovery of attorney's fees by prevailing parties and then presents the Buckhannon decision-both the majority opinion and Justice Ginsburg's dissent. Part II examines current law on the question of Buckhannon's applicability to the EAJA. Of the relatively few courts that have addressed the issue, most have applied Buckhannon's narrower definition of prevailing party to the EAJA; however, one court has distinguished Buckhannon, holding it inapplicable to the EAJA. Part III argues that the Supreme Court's rejection of the catalyst theory in Buckhannon should not extend to the EAJA and that a broader definition of prevailing party is appropriate for that statute. Textually, Buckhannon limits its applicability to the ADA and FHAA. Even more importantly, those statutes are distinguishable from the EAJA (in language, stated rationale, and integral components) such that Buckhannon simply is not applicable. The legislative purpose and history of the EAJA further separate it from the statutes at issue in Buckhannon; these demonstrate that Buckhannon's definition of prevailing party is inconsistent with the EAJA and that, rather, a definition of prevailing party including the catalyst theory was intended by Congress. Moreover, various policy considerations counsel against application of Buckhannon to the EAJA. Therefore, this Comment concludes that the EAJA is not and should not be bound by Buckhannon's interpretation of prevailing party.

1998). The EAJA provides for awards of attorney's fees to parties prevailing against the United States in certain judicial and agency proceedings.

8 Compare Perez-Arellano v Smith, 279 F3d 791 (9th Cir 2002) (extending Buckhannon); Alcocer v INS, 2001 US Dist LEXIS 20543, *5-8 (N D Tex 2001) (same); Thayer v Principi, 15 Vet App 204 (2001) (same), with Brickwood Contractors, Inc v United States, 49 Fed Cl 738, 74950 (2001) (distinguishing Buckhannon). 


\section{FEE SHIFTING AND THE EAJA}

\section{A. Background}

Litigants in the United States traditionally must bear their own attorney's fees, regardless of whether they win or lose.' Judicially fashioned exceptions to this "American Rule" have evolved at common law, but these exceptions are narrow. ${ }^{10}$ In addition, however, Congress has created statutory exceptions to the American Rule that allow recovery of attorney's fees under certain circumstances. Numerous federal statutes include fee-shifting provisions making fees awardable to prevailing parties."

Exceptions to the American Rule are not as tightly confined as they once were, and fee shifting has increasingly been used to encourage litigation that is considered beneficial to society. ${ }^{12}$ One of the most significant and often-cited reasons for limiting the American Rule has been to enable private enforcement of public policy. ${ }^{13}$ Fee shifting promotes suits by citizens and, thus, helps them act as "private attorneys general. ${ }^{14}$

In keeping with this congressional policy of encouraging private enforcement of public policy, some courts in the 1960s and 1970s permitted fee shifting where the litigant was promoting the public inter-

9 See Alyeska Pipeline Service Co v Wilderness Society, 421 US 240, 247 (1975) ("In the United States, the prevailing litigant is ordinarily not entitled to collect a reasonable attorney's fee from the loser."). This contrasts with other judicial systems, such as that of England, in which the prevailing party recovers from the loser. See id (stating that in England "counsel fees are regularly allowed to the prevailing party"). The practice of the American system was recognized as early as 1796. Id at 249. See also Arcambel $v$ Wiseman, 3 US (3 Dall) 306, 306 (1796) (stating that the general practice in America is against inclusion of attorney's fees as damages). For a detailed discussion of the American rule, see John Leubsdorf, Toward a History of the American Rule on Attorney Fee Recovery, $47 \mathrm{~L}$ \& Contemp Probs 9 (1984).

10 See Charles R. Haywood, Comment, The Power of Bankruptcy Courts to Shift Fees Under the Equal Access to Justice Act, 61 U Chi L Rev 985, 987 (1994) ("Common law exceptions, however, have narrow applicability and are geared toward redressing specific injustices after litigation."). See also Claire Elizabeth Winold, Comment, Institutionalizing an Experiment: The Extension of the Equal Access to Justice Act-Questions Resolved, Questions Remaining, $14 \mathrm{Fla} \mathrm{St} \mathrm{U}$ L Rev 925, 925-26 (1987) (providing examples of judge-made exceptions).

11 See Marek $v$ Chesny, 473 US 1, 43-51 (1985) (Brennan dissenting) (appendix) (listing federal fee-shifting statutes).

12 Haywood, Comment, $61 \mathrm{U}$ Chi L Rev at 988 (cited in note 10) (describing modern use of fee-shifting). See also Dan B. Dobbs, Awarding Attomey Fees Against Adversaries: Introducing the Problem, 1986 Duke L J 435, 446 (considering public benefit as one possible justification for fee-shifting).

13 See Haywood, Comment, $61 \mathrm{U}$ Chi L Rev at 988 (cited in note 10) (discussing private enforcement of public policy as a fee-shifting rationale); Winold, Comment, 14 Fla St U L Rev at 926-27 (cited in note 10) (same). See also John J. Sullivan, Note, The Equal Access to Justice Act in the Federal Courts, 84 Colum L Rev 1089, 1090-92 (1984) (discussing the "erosion of the American Rule" and the events leading up to the enactment of the EAJA).

14 Haywood, Comment, 61.U Chi L Rev at 988 (cited in note 10) (discussing the private attorney general rationale). 
est, even in the absence of specific statutory fee-shifting authority. ${ }^{\text {is }}$ In 1975, the Supreme Court disapproved of this judicial expansion of the private attorney general concept, re-emphasized the American Rule, and forbade fee shifting absent specific statutory or common law authority. ${ }^{16}$ Congress immediately responded by expanding statutory feeshifting authority in order to preserve the private enforcement of public policy." Beginning with the Civil Rights Attorney's Fees Awards Act of $1976,{ }^{18}$ it proceeded to pass statutes that provided for fee shifting for the public benefit. ${ }^{19}$ Congressional action culminated in the passage of the EAJA in 1980, which marked an unprecedented move to expand the statutory exceptions to the American Rule.

\section{B. The EAJA}

The EAJA has two major components. First, the statute includes a waiver of sovereign immunity, so that the government is subject to fee shifting like any private litigant." Second, and more importantly, the EAJA contains a fee-shifting provision for the recovery of fees by a prevailing party-plaintiff or defendant-in a nontort civil action against the United States. The prevailing party is entitled to recover unless the position of the United States was "substantially justified" or

15 See id at 988-89 (discussing courts' allowance of fee-shifting in this context); see also Winold, Comment, $14 \mathrm{Fla}$ St U L Rev at 927 (cited in note 10) (same); Sullivan, Note, 84 Colum $\mathrm{L}$ Rev at 1091 (cited in note 13) (same).

16 Alyeska, 421 US at 263 ("[C]ongressional utilization of the private-attorney-general concept can in no sense be construed as a grant of authority to the Judiciary to jettison the traditional rule ... and to award attorneys' fees whenever the courts deem the public policy furthered by a particular statute important enough to warrant the award.").

17 Haywood, Comment, 61 U Chi L Rev at 989 (cited in note 10) (discussing Congress's reaction to Alyeska).

18 Pub L No 94-559, 90 Stat 2641, codified at 42 USC $\$ 1988$ (b) (1994).

19 Haywood, Comment, 61 U Chi L Rev at 989 (cited in note 10) (discussing Congress's enactment of fee-shifting statutes after Alyeska).

20 See id at 990 (discussing the EAJA's enactment); Winold, Comment, 14 Fla St U L Rev at 929 (cited in note 10) (same).

21 See 28 USC \$ 2412(b) ("The United States shall be liable for [ ] fees and expenses to the same extent that any other party would be liable under the common law or under the terms of any statute which specifically provides for such an award."). Therefore, the federal government no longer is exempt from the common law fee-shifting provisions. See Haywood, Comment, $61 \mathrm{U}$ Chi L Rev at 990 (cited in note 10) (discussing the EAJA's waiver of sovereign immunity); Winold, Comment, 14 Fla St U L Rev at 929-30 (cited in note 10) (same).

22 See 28 USC $\$ 2412(d)(1)(A)$ :

[A] court shall award to a prevailing party other than the United States fees and other expenses, ... incurred by that party in any civil action (other than cases sounding in tort) ... brought by or against the United States ..., unless the court finds that the position of the United States was substantially justified or that special circumstances make an award unjust. 
unless an award would be unjust. ${ }^{23}$ The EAJA provides for fee shifting in administrative adjudications as well. ${ }^{24}$

In general, the EAJA mandates fee awards against the United States to private litigants in certain situations. ${ }^{25}$ The statute's stated purpose is "to diminish the deterrent effect of seeking review of, or defending against, governmental action" ${ }^{26}$ and to ensure that common law and statutory exceptions to the American Rule apply in actions involving the United States. ${ }^{27}$ Recognizing not only the expense of vindicating one's rights in litigation but the greater resources and expertise of the government, Congress attempted to place private citizens and businesses on more equal footing with the United States.

\section{Prevailing Party in Fee-shifting Statutes Prior to Buckhannon}

Prior to Buckhannon, "prevailing party" was construed in a flexible fashion and the use of the catalyst theory to determine whether a party seeking attorney's fees had prevailed was well established. Under the catalyst theory, if a party brings about a voluntary change in the defendant's conduct, it qualifies as a prevailing party and can recover attorney's fees. ${ }^{29}$ The existence of a formal victory is not a re-

23 Id. The EAJA represents a form of one-way fee-shifting: the government may be held liable for attorney's fees but may not assert the liability of others. See Dobbs, 1986 Duke L J at 448-49 (cited in note 12) (discussing one-way fee shifting and mentioning the EAJA). Thus, the EAJA makes a distinction between government and citizen rather than the more typical plaintiff/defendant distinction, which is found in many statutes authorizing fee awards only to prevailing plaintiffs. Id.

24 See 5 USC § 504(a)(1) ("An agency that conducts an adversary adjudication shall award, to a prevailing party other than the United States, fees and other expenses incurred by that party in connection with that proceeding, unless ... the position of the agency was substantially justified or that special circumstances make an award unjust.").

25 See EAJA, 94 Stat 2325.

26 Id at $\$ 202(\mathrm{c})(1)$.

27 Id at $\$ 202(c)(2)$.

28 See id at $\S 202$ (a) ("The Congress finds that certain individuals, partnerships, corporations, and labor and other organizations may be deterred from seeking review of, or defending against, unreasonable governmental action because of the expense involved in securing the vindication of their rights in civil actions and in administrative proceedings."). See also id at \$ 202(b) ("The Congress further finds that because of the greater resources and expertise of the United States the standard for an award of fees against the United States should be different from the standard governing an award against a private litigant, in certain situations."); Equal Access to Justice Act, HR Rep No 96-1418, 96th Cong, 2d Sess 1, 9 (1980) ("strong movement by Congress toward placing the Federal Government and civil litigants on a completely equal footing").

29 See Marbley $v$ Bane, 57 F3d 224, 233-34 (2d Cir 1995) (recognizing the catalyst theory as a viable form of recovery as a prevailing party). See also Hewitt v Helms, 482 US 755, 760-61 (1987) (declaring that when a lawsuit produces voluntary action by the defendant that affords the plaintiff all or some of the relief he sought through a judgment, the plaintiff is deemed to have prevailed despite the absence of a formal judgment in his favor). While Hewitt discusses the catalyst theory and seems to indicate its viability, that issue was not decided by the Court, and the language relating thereto is, therefore, dicta. See Buckhannon, 532 US at $603 \mathrm{n} 5$ (discussing 
quirement for prevailing-party status, ${ }^{30}$ and an award may be justified where a plaintiff can show that the lawsuit "accomplished the original objectives of the lawsuit without a formal judgment.",

Although the Supreme Court never had specifically ruled on whether catalysts qualified as prevailing parties, an overwhelming majority of the federal courts of appeals recognized the theory's viability. ${ }^{32}$ Only the Fourth Circuit has held the catalyst theory invalid, ${ }^{33}$ basing its decision on statements made by the Supreme Court in Farrar $v$ $H o b b y,{ }^{34}$ a case involving attorney's fees. The Farrar Court determined that a plaintiff who receives nominal damages is a prevailing party. Farrar "involved no catalytic effect," however, so the language on which the Fourth Circuit relied was dicta. ${ }^{36}$ Following the Fourth Circuit's decision, nine courts of appeals reaffirmed that prevailing-party status may be achieved when the suit acts as a catalyst for the change that was sought, even in the absence of an enforceable judgment, consent decree, or settlement.

Hewitt).

30 See Stanton v Southern Berkshire Regional School District, 197 F3d 574, 577 (1st Cir 1999) ("[A] plaintiff may ... deserve attorney's fees, even without a formal victory.").

31 Baumgartner v Harrisburg Housing Authority, 21 F3d 541, 551 (3d Cir 1994) (holding that "there is no legal impediment to application of the 'catalyst theory' to show that plaintiffs were 'prevailing parties' notwithstanding the absence of a judgment or consent decree").

32 See, for example, Nadeau v Helgemoe, 581 F2d 275, 279-81 (1st Cir 1978) (approving of recovery as a catalyst under 42 USC $\S 1988$ ); Gerena-Valentin v Koch, 739 F2d 755, 758-59 (2d Cir 1984) (Voting Rights Act of 1965); Institutionalized Juveniles v Secretary of Public Welfare, 758 F2d 897, 910-17 (3d Cir 1985) (Section 1988); Bonnes v Long, 599 F2d 1316, 1319 (4th Cir 1979) (same); Robinson v Kimbrough, 652 F2d 458, 465-67 (5th Cir 1981) (same); Citizens Against Tax Waste v Westerville City School District Board of Education, 985 F2d 255, 257-58 (6th Cir 1993) (same); Hendricks v Bowen, 847 F2d 1255, 1258 (7th Cir 1988) (EAJA); Williams $v$ Miller, 620 F2d 199, 202 (8th Cir 1980) (Emergency School Aid Act of 1972 and Section 1988); American Constitutional Party v Munro, 650 F2d 184, 187-88 (9th Cir 1981) (Section 1988); $J$ \& $J$ Anderson, Inc v Town of Erie, 767 F2d 1469, 1474-75 (10th Cir 1985) (same); Doe v Busbee, 684 F2d 1375, 1379 (11th Cir 1982) (same); Grano v Barry, 783 F2d 1104, 1108-10 (DC Cir 1986) (same).

33 See S-1 and S-2 v State Board of Education of North Carolina, 21 F3d 49, 51 (4th Cir 1994) (en banc) ("A person may not be a 'prevailing party' plaintiff ... except by virtue of having obtained an enforceable judgment, consent decree, or settlement."), citing Farrar v Hobby, 506 US 103, 111 (1992).

34506 US 103, 112-16 (1992) (denying recovery of attorney's fees under Section 1988 to a plaintiff who was a prevailing party but who had recovered nominal damages of only one dollar on a claim for seventeen million dollars in compensatory damages).

35 Id at 112 ("We therefore hold that a plaintiff who wins nominal damages is a prevailing party.").

36 Friends of Earth, Inc $v$ Laidlaw Environmental Services (TOC), Inc, 528 US 167, 194-95 (2000) (commenting that the catalyst theory was not at issue in Farrar but refraining from addressing the continued viability of the catalyst theory).

37 See Buckhannon, 532 US at 627 \& n 5 (Ginsburg dissenting), citing Stanton, 197 F3d at 577 n 2 (recognizing the viability of the catalyst theory under 42 USC § 1988); Morris y West Palm Beach, 194 F3d 1203, 1207 (11th Cir 1999) (same); Payne v Board of Education, 88 F3d 392, 397 (6th Cir 1996) (Individuals with Disabilities Education Act); Marbley, 57 F3d at 234 (Section 1988); Kilgour v Pasadena, 53 F3d 1007, 1010 (9th Cir 1995) (same); Beard v Teska, 31 F3d 942, 


\section{The Buckhannon Decision}

In Buckhannon, a 5-4 Supreme Court announced a more restrictive concept of prevailing party under the ADA and FHAA that definitively excluded the catalyst theory as a permissible basis for an award of attorney's fees under those statutes. The Buckhannon Court held that to be eligible as a prevailing party, a party must secure a judgment on the merits or a court-ordered consent decree, rather than merely achieving the desired result in the lawsuit by bringing about a voluntary change in the defendant's conduct. ${ }^{39}$ While the Court recognized that most courts of appeals allowed catalysts to collect as prevailing parties, ${ }^{40}$ it nonetheless embraced the opposite view. ${ }^{41}$

Writing for the majority, Chief Justice Rehnquist turned to Black's Law Dictionary for a definition of prevailing party as "[a] party in whose favor a judgment is rendered, regardless of the amount of damages awarded." ${ }^{42}$ Distilling from prior cases this idea that a prevailing party is one that has been granted some judicial relief, Rehnquist concluded that enforceable judgments on the merits and court-ordered consent decrees create the "material alteration of the legal relationship of the parties" necessary to permit an award of attorney's fees. ${ }^{43}$ The catalyst theory, on the other hand, would allow an award where there was no judicially sanctioned change in the legal relationship of the parties; therefore, it was impermissible. ${ }^{4}$ A voluntary

951-52 (10th Cir 1994) (Individuals with Disabilities Education Act); Zinn v Shalala, 35 F3d 273, 276 (7th Cir 1994) (Section 1988); Baumgartner, 21 F3d at 546-50 (same); Little Rock School District v Pulaski County School District, No 1, 17 F3d 260, 263 n 2 (8th Cir 1994) (same).

38 Buckhannon Board and Care Home, Inc, a provider of assisted living, failed a state fire inspection. 532 US at 600 . Upon receiving orders to close, Buckhannon sued the State of West Virginia, seeking both declaratory and injunctive relief that the requirement they had failed to meet violated the FHAA and ADA. Id at 600-01. When the West Virginia legislature mooted the case bys eliminating the requirement, the suit was dismissed. Id at 601 . Invoking the catalyst theory, Buckhannon filed for attorney's fees as the prevailing party under the FHAA and ADA. Id.

39 Id at 603-06.

40 Id at 601-02.

41 Id at 605 .

42 Id at 603. Chief Justice Rehnquist did so after mentioning that the statutes at issue provide an exception to the American Rule and are among a number of statutes in which Congress has authorized the award of attorney's fees to the prevailing party. Id. He listed as examples the Civil Rights Act of 1964, 78 Stat 259, the Voting Rights Act Amendments of 1975, 89 Stat 402, and the Civil Rights Attorney's Fees Awards Act of 1976,90 Stat 2641, and cited Marek $v$ Chesny, 473 US 1, 43-51 (1985) (Brennan dissenting) (appendix) (listing federal fee-shifting statutes). Buckhannon, 532 US at 602-03. Rehnquist noted that he would interpret the "nearly identical" provisions at issue consistently, as that had been the practice with these fee-shifting provisions, and cited Hensley $v$ Eckerhart, 461 US 424, 433 in 7 (1983) (noting that the standards set forth with regard to $\S 1988$ are generally applicable to fee-shifting statutes authorizing fee awards to prevailing parties). Buckhannon, 532 US at $603 \mathrm{n} 4$.

43 Id at 603-04.

44 Id at 605. Rehnquist emphasized the danger inherent in even a limited form of the catalyst theory: a complaint that had sufficient merit to withstand a motion to dismiss for lack of ju- 
change in the defendant's conduct may produce what the plaintiff sought to achieve, but it "lack[s] the necessary judicial imprimatur on the change.".

The Buckhannon Court found arguments for adoption of a broader definition of prevailing party unpersuasive. The majority discounted the view that the legislative history of the Civil Rights Attorney's Fees Awards Act ${ }^{46}$ compels a reading of prevailing party that encompasses the catalyst theory. The Court believed the cited materials were "at best ambiguous as to the availability of the "catalyst theory" and would not suffice to change the accepted meaning of prevailing party, especially in light of the "explicit statutory authority" required for an exception to the American Rule." The Buckhannon Court also was unconcerned that rejection of the catalyst theory might deter plaintiffs with "meritorious but expensive" cases from bringing suit." In addition, the Court dismissed the idea that the catalyst theory was necessary to prevent defendants from unilaterally mooting an action before judgment in order to avoid paying attorney's fees. ${ }^{s_{0}}$ On the other hand, it was troubled by the potential disincentive that the catalyst theory might create for a defendant to change its conduct voluntarily. ${ }^{\text {st }}$ Finally, the Court was hesitant to adopt an interpretation of the fee-shifting statutes that would "spawn[ ] a second litigation of significant dimension," which might occur if courts were required to determine if a party indeed had acted as a catalyst. ${ }^{52}$ The majority did not deem it necessary to examine these policy issues, however, because it purportedly rested its decision on the clear meaning of prevailing party.

risdiction or failure to state a claim on which relief may be granted could allow a plaintiff to recover attorney's fees. Id.

45 Id. The majority indicated its concern that inclusion of the catalyst theory would "abrogate the 'merit' requirement" and allow fee-shifting where the claim was "at least colorable" and non-frivolous. Id at 606.

4690 Stat 2641.

47 Buckhannon, 532 US at 607 . The Court addressed this argument, however, because it had relied on such legislative history in earlier cases. Id.

48 Id at 607-08. The legislative history consisted of a House Report stating that prevailing party is "not intended to be limited to the victor only after entry of a final judgment following a full trial on the merits," a Senate Report explaining that "parties may be considered to have prevailed when they vindicate rights through a consent judgment or without formally obtaining relief," and a reference to a case decided six years before the Act in which a plaintiff, who had obtained an enforceable judgment, was awarded attorney's fees as a prevailing party. Id at 607-08 \& $\mathrm{n} 9$.

49 Id at 608.

50 Id at 608-09.

51 Id.

52 Id at 609 . The Court was concerned with the difficulties involved in making the necessary factual determinations, particularly in judging the defendant's subjective motivations in voluntarily changing its conduct. Id at 609-10.

53 Id at 610 . 
Criticizing the majority's definition of prevailing party as uncompelled by history, precedent, or the plain meaning of the relevant statutes, Justice Ginsburg dissented. She took issue with the fact that the rule adopted by the majority pivots on a technicality - the filing of a court document-rather than resting on the actual merits of the case. Furthermore, she highlighted the negative impact that the narrower definition would have on civil rights litigation. ${ }^{36}$ More specifically, the Court's rejection of the catalyst theory "impede[s] access to court for the less well-heeled, and shrink[s] the incentive Congress created for the enforcement of federal law by private attorneys general."." According to Justice Ginsburg, “the 'catalyst rule,' as applied by the clear majority of Federal Circuits, is a key component of the fee-shifting statutes Congress adopted to advance enforcement of civil rights." ${ }^{\text {ss }}$

Specifically, Justice Ginsburg found fault with the majority on the following grounds. First, she noted that the dictionary definition employed by the majority was not inconsistent with a reading of prevailing party that encompasses the catalyst theory, and in prior cases, statutory terms of art have been given a contextual reading by the Court. ${ }^{59}$ Additionally, the prevailing party language in the fee-shifting provisions at issue stands in contrast to provisions of other statutes that foreclose a catalyst theory. ${ }^{60}$ Justice Ginsburg also garnered support for the viability of the catalyst theory from the ordinary and common meaning of prevailing party, as illustrated by Webster's Dictionary. ${ }^{61}$ According to this meaning, a party in a lawsuit prevails when it achieves the actual relief sought; a judgment is the means of attaining that goal, not the end. ${ }^{62}$

Justice Ginsburg also argued that the catalyst theory appropriately advances Congress's objective in the modern fee-shifting statutes of extending "civil rights protections and enforcement measures." Moreover, she found that the catalyst theory seems to have been

54 Id at 622-44. This case also includes a concurrence by Justice Scalia, in which he agreed with the majority's opinion but responded in more detail to the contentions of the dissent. Id at 610-22 (Scalia concurring).

55 Id at 622-23 (Ginsburg dissenting). Justice Ginsburg pointed out that the required "court entry memorializing [a] victory" need not be a judgment on the merits and does not require any finding of wrongdoing, since a court-approved settlement would suffice. Id at 622 . Conversely, a defendant who was driven by the merits of the case to grant the plaintiff's desired relief may escape unscathed. Id.

56 Id at 623 .

57 Id.

58 Id.

59 Id at 628-29.

60 Id at $629-30$.

61 Id at 633-34.

62 Id at 634, citing Hewitt $v$ Helms, 482 US 755, 761 (1987) (describing the judicial decree as the means not the end and stating that the goal is the defendant's change in conduct).

63 Buckhannon, 532 US at 635. 
within the definition of prevailing party envisioned by Congress. ${ }^{64}$ She then addressed the policy issues hinted at by the majority, countering the concerns related to inclusion of the catalyst theory.

Lastly, the dissent explained that when deciding the viability of the catalyst theory, reliance on the practical impact of the lawsuit (and not any "judicial imprimatur") would be most consistent with the Court's attorney fee precedents. Justice Ginsburg further declared that if the term "prevailing party" in fee-shifting statutes has an "accepted meaning," then it is the one "accepted by every Court of Appeals to address the catalyst issue before our 1987 decision in Hewitt and disavowed since then only by the Fourth Circuit." ${ }^{67}$

\section{CURRENT LAW: BUCKHANNON'S APPLICABILITY TO THE EAJA}

The applicability of Buckhannon to other federal statutes like the EAJA that contain fee-shifting provisions for prevailing parties is unclear. Courts disagree as to whether Buckhannon's rejection of the catalyst theory compels'a finding that the catalyst theory is no longer available to achieve prevailing-party status under the EAJA.

\section{A. The Majority Position: Buckhannon's Definition of "Prevailing Party" Applies to the EAJA}

Several courts have extended Buckhannon's rejection of the catalyst theory to the EAJA, ${ }^{68}$ basing their decisions in large part upon the note in Buckhannon that fee-shifting provisions have been interpreted consistently. ${ }^{69}$ In Sileikis v Perryman, ${ }^{70}$ one district court held that in light of Buckhannon, the catalyst theory is no longer available under

64 Id at 637-38. Unlike the majority, the dissent, in accordance with the longstanding view of the courts of appeals, judged the House and Senate Reports mentioned above, see notes $46-48$ and accompanying text, to be "hardly ambiguous." Id at 638.

65 Id at 638-40. The dissent pointed out that contrary to the view that defendants would resist changing their behavior to keep payment of attorney's fees at bay, one might find that the catalyst theory would bring about prompt compliance with the law, because prolonged litigation is expensive. Id at 639. In fact, the expense of noncompliance may encourage compliance before litigation. Id. The dissent also explained that rather than becoming a burden on the courts, the catalyst theory actually may save judicial resources by encouraging the cessation of litigation after the relief sought has been granted by the defendant. Id at 639-40.

66 Id at 641 ("It bears emphasis, however that in determining whether shifting is in order, the court in the past has placed greatest weight not on any 'judicial imprimatur,' but on the practical impact of the lawsuit.")

67 Id at 643 (internal citations omitted).

68 Just prior to publication, the Ninth Circuit handed down a decision extending Buckhannon's definition of "prevailing party" to the EAJA. See Perez-Arellano v Smith, 279 F3d 791, 794 (9th Cir 2002) ("[W]e discern no reason to interpret the EAJA inconsistently with the Supreme Court's interpretation of 'prevailing party' in the FHAA and the ADA as explained in Buckhannon.").

69 See note 42.

702001 US Dist LEXIS 12737 (N D Ill). 
the EAJA." The court discussed Buckhannon's observation that the Supreme Court had always interpreted fee-shifting provisions consistently and the fact that Buckhannon cited to the list of fee-shifting statutes found in Marek $v$ Chesny, ${ }^{2}$ which includes the EAJA. ${ }^{3}$ In addition, the court shared Buckhannon's concern that the catalyst theory might deter the defendant from voluntarily altering its conduct and would require the court's analysis of the defendant's subjective motivations. ${ }^{74}$ Accordingly, the Sileikis court rejected the catalyst theory under the EAJA. ${ }^{75}$

In Alcocer $v I N S{ }^{76}$ another district court denied prevailing-party status to plaintiffs seeking it under the catalyst theory; but the court did not explicitly pronounce the catalyst theory unavailable under the EAJA in light of Buckhannon." The court stated that "although the United States Supreme Court did not mention attorney's fees under the EAJA in Buckhannon, it strongly insisted a court respect ordinary language in its interpretation of the term "prevailing party.", In a note, the court mentioned Buckhannon's statement regarding the numerous fee-shifting statutes and its note about their consistent interpretation; yet, the court cited a recent federal claims case ${ }^{79}$ that created an exception for the definition of prevailing party under the EAJA. It also discussed a Fifth Circuit Court of Appeals case ${ }^{81}$ that, on the basis of Buckhannon, rejected reliance on the catalyst theory to achieve prevailing-party status with respect to fee-shifting statutes and refused an award under the Civil Rights Attorney's Fee Act.

71 See id at $* 8-9$ (holding the catalyst theory unavailable under the EAJA for a plaintiff whose requested relief was granted by the defendant without the court's intervention).

72473 US 1, 43-51 (1985) (Brennan dissenting) (appendix to the dissent containing a list of federal fee-shifting statutes).

73 Sileikis, 2001 US Dist Lexis 12737 at $* 5-6$. The court also mentioned several recent cases, not involving the EAJA, which discussed or applied the rule in Buckhannon. Id at *6-8.

74 Id at $\neq 8-9$.

75 Id.

762001 US Dist LEXIS 20543 (N D Tex).

77 Id at $* 6-9$. In Alcocer, plaintiffs filed for adjusted status and the INS subsequently interviewed them, determining that the marriage might be fraudulent and an investigation must be conducted. Id at $\approx 2$. Two years later, plaintiffs filed the complaint at issue, seeking adjudication. Id. Shortly after the US attorney was served with the complaint, the INS granted adjusted status to the plaintiffs, mooting the subject matter of the suit. Id at $* 2-3$. Plaintiffs sought attorney's fees. Id at $* 3$.

78 Id at $\approx 8$. Note that Justice Ginsburg reached the opposite conclusion on the basis of ordinary language. See text accompanying notes $61-62$.

79 Brickwood Contractors, Inc v United States, 49 Fed Cl 738 (2001) (distinguishing Buckhannon). See Part II.B.

so Alcocer, 2001 US Dist LEXIS 20543 at $* 8$ n 5.

81 Johnson v Rodriguez, 260 F3d 493, 495 (5th Cir 2001) ("The Supreme Court has since rejected reliance on the 'catalyst theory' as a basis for awarding attorney's fees under fee-shifting statutes authorizing awards to the "prevailing party."').

82 Alcocer, 2001 US Dist LEXIS 20543 at $* 8$ n 5 . 
Alcocer examined Buckhannon's examples of what judicial outcomes are permissible for prevailing-party status (an enforceable judgment on the merits or settlement agreement enforceable through a court-ordered consent decree). ${ }^{\text {si }}$ The court then explained that it had not considered the merits of the plaintiffs' claims nor granted any relief in the lawsuit that changed the legal relationship between the parties. ${ }^{84}$ The relief sought by the plaintiffs was granted extraneously, but they "did not prevail in the lawsuit in any plausible sense of the word." $"$ As a result, the court denied attorney's fees. ${ }^{86}$

In Former Employees of Motorola Ceramic Products $v$ United States, ${ }^{87}$ the United States Court of International Trade ("CIT") applied Buckhannon by requiring a judicially sanctioned change in parties' legal relationship for qualification as a prevailing party, even when the plaintiff's legal action served as a catalyst for positive results. ${ }^{\text {sy }}$ According to the court, Buckhannon did not limit its applicability to the ADA, FHAA, and other statutes specifically listed in the opinion, because it based its interpretation of prevailing party on statutes other than those at issue in the case. ${ }^{89}$ The CIT, like the district courts, relied on Buckhannon's reference to the numerous fee-shifting statutes authorizing an award of attorney's fees to a prevailing party and Buckhannon's statement that it has interpreted those statutes consistently." Because the court did not award the plaintiffs relief through an enforceable judgment on the merits or a court-ordered consent decree, they were not prevailing parties."

The Court of Appeals for Veterans Claims also has held that the catalyst theory no longer is available to attain prevailing-party status under the EAJA. ${ }^{92}$ In Thayer $v$ Principi, ${ }^{93}$ it stated that "the language of [the EAJA] as compared to the FHAA and ADA, coupled with the

83 Id at $* 8$.

84 Id.

85 Id, citing Hewitt $v$ Helms, 428 US 755, 760 (1987) (stating that to prevail, a party must receive at least some relief on the merits of the claim).

86 Alcocer, 2001 US Dist LEXIS 20543 at *9.

$87176 \mathrm{~F}$ Supp 2d 1370 (Ct Intl Trade 2001).

88 Id at 1372-74.

89 Id at 1373 .

90 Id

91 Id. The court recognized the decision in Brickwood Contractors, Inc $v$ United States, 49 Fed $\mathrm{Cl} 738$ (2001), but found that even though the EAJA requires a decision on the merits of the case, such a decision is not required for a determination of prevailing-party status. Id at $1373 \mathrm{n} 3$. The court was "guided by" Buckhannon, because the EAJA contains the same prevailing party requirement as the statutes listed in Buckhannon. Id.

92 See, for example, Thayer v Principi, 15 Vet App 204, 211 (2001) ("the catalyst theory is no longer available to achieve prevailing-party status in this Court"); Parsons v Principi, 2002 US App Vet Claims LEXIS 12 (following Thayer); Dollar $v$ Principi, 2001 US App Vet Claims LEXIS 1516 (same).

9315 Vet App 204, 211 (2001). 
structure and content of the Supreme Court's opinion in Buckhannon, demonstrates that the definition of 'prevailing party' set forth by the Supreme Court in Buckhannon applies to" the EAJA." First, the court concluded that the fee-shifting provisions of EAJA are more similar than not to those of the ADA and the FHAA and should, therefore, be interpreted consistently. Second, the court was not convinced that a different definition of prevailing party was warranted due to the EAJA's "substantially justified" requirement." The court found that the definition of prevailing party was not directly affected by the existence of that requirement. ${ }^{97}$ The court pointed to Buckhannon's mention of the numerous fee-shifting statutes, its note about consistent interpretation, and its cite to the Marek appendix ${ }^{93}$ as indications that the statutes should be interpreted consistently." Also, Buckhannon's reference to many of the same opinions relied upon by the court in developing its case law on the EAJA and the catalyst theory suggests Buckhannon's relevance to the EAJA. ${ }^{100}$ Finally, the court shared the Supreme Court's concern with the difficulty of determining a defendant's subjective motivation in changing its conduct if the catalyst theory were applied. ${ }^{101}$

\section{B. Brickwood: Buckhannon's Definition of Prevailing Party Does Not Apply to the EAJA}

In Brickwood Contractors, Inc v United States, ${ }^{102}$ the Court of Federal Claims held that Buckhannon's exclusion of the catalyst theory is not binding on the EAJA. ${ }^{103}$ The court distinguished Buckhannon from

94 Id at 211. In Thayer, while the veteran was in the process of appealing the denial of his claim for service connection for schizophrenia, he was awarded such a service connection and the appeal was mooted. Id at 205. He filed for attorney's fees under the EAJA. Id.

95 Id at 208.

96 Id at 209. See 28 USC $\S 2412$ (d)(1)(A) ("[A] court shall award to a prevailing party ... unless the court finds that the position of the United States was substantially justified or that special circumstances make an award unjust.").

97 Thayer, 15 Vet App at 209.

98 See note 42.

99 Id at 209-10. The court further notes that prevailing party should be read consistently throughout all sections of the EAJA and discounts the argument that the EAJA is not a statute "authorizing" a fee award for a prevailing party merely because it mandates such an award. Id at 210.

100 Id at 210-11.

101 Id at 211.

10249 Fed Cl 738 (2001).

103 Id at 747. Prior to the Supreme Court's holding in Buckhannon, a contractor filed a bid protest action against the government, seeking to prevent the Navy from converting an invitation for bids to a request for proposals and to have the contract awarded to itself. Brickwood Contractors, Inc $v$ United States, 49 Fed Cl 148, 150 (2001). As a result of the suit, the Navy cancelled the solicitation and offered a new one, instead of pursuing the conversion. Id. The case was then dismissed as moot and the contractor sought attorney's fees. Id at 150-51. Relying on the catalyst theory, the court awarded the contractor attorney's fees as the prevailing party, even 
cases under the EAJA, distinguished the EAJA from the statutes in Buckhannon, and emphasized several policy issues. ${ }^{104}$ First, the court observed that the holding in Buckhannon specifically applies to the ADA and the FHA. ${ }^{105}$ Chief Justice Rehnquist indicates this limitation in the last sentence of the opinion, which states, "we hold that the 'catalyst theory' is not a permissible basis for the award of attorney's fees under the FHAA and ADA.."106 In addition, the court observed that the EAJA was not mentioned in the Buckhannon opinion. ${ }^{107}$ Furthermore, the court pointed out that the note that the prevailing-party provisions in other fee-shifting statutes have been interpreted consistently and the three statutes listed as examples ${ }^{108}$ were dicta. ${ }^{109}$ Moreover, it maintained that the decision can be distinguished factually on the basis that the lawsuit filed by the Buckhannon plaintiffs did not cause a change in the defendant's behavior: the legislature, not a party to the lawsuit, independently acted to cause the case to become moot. ${ }^{110}$

Most importantly, the court found that the plain language of the statutes directly at issue in Buckhannon and those specifically listed in that case contrasts with that of the EAJA, so Buckhannon's definition is not appropriate. ${ }^{\text {II }}$ The fee-shifting provisions of the statutes at issue in Buckhannon (the ADA and the FHAA) afford broad discretion to the trial court in determining whether to award a prevailing party attorney's fees and contain no requirement for review of the underlying merits of the case. ${ }^{112}$ The Buckhannon Court also named three federal fee-shifting statutes which have been consistently interpreted

though there had been no final judgment on the merits, because the plaintiff had "significantly contributed to producing a 'voluntary action by the defendant that affords the plaintiff all or some of the relief [it] sought through a judgment."' Id at 156, quoting Hewitt $v$ Helms, 482 US 755, 760 (1987). After the Buckhannon decision, the defendant filed a motion for relief from judgment, arguing that the newly issued decision invalidated the catalyst theory as a means of achieving prevailing-party status under federal attorney's fee statutes. Brickwood, $49 \mathrm{Fed} \mathrm{Cl}$ at $740-41$.

104 Id at $743-49$.

105 Id at 744.

106 Id at 743, citing Buckhannon, 532 US at 610 (internal citations omitted).

107 Brickwood, $49 \mathrm{Fed} \mathrm{Cl}$ at 744.

108 Civil Rights Act of 1964, 78 Stat 259; Voting Rights Act Amendments of 1975, 89 Stat 402; Civil Rights Attorney's Fees Awards Act of 1976,90 Stat 2641.

109 Brickwood, $49 \mathrm{Fed} \mathrm{Cl}$ at 744.

110 Id. See note 38. In fact, the legislature's action allowed the defendants to change their behavior without violating the law. Brickwood, $49 \mathrm{Fed} \mathrm{Cl}$ at 744 .

111 Brickwood, $49 \mathrm{Fed} \mathrm{Cl}$ at 745-47.

112 Id at 745. See ADA, 104 Stat 327, 371 ("In any action or administrative proceeding commenced pursuant to this Act, the court or agency, in its discretion, may allow the prevailing party, other than the United States, a reasonable attorney's fee, including litigation expenses, and costs."); FHAA, 102 Stat 1619, 1633 ("In . . . any civil action ..., the court, ... in its discretion, may allow the prevailing party, other than the United States, a reasonable attorney's fee and costs."). 
with the ADA and FHAA, and the EAJA was not among these. ${ }^{113}$ The court explained that these three statutes contain language similar to the ADA and FHAA, providing the same broad discretion and lacking any requirement for a meritorious review. ${ }^{14}$ The EAJA, on the other hand, mandates that an award of attorney's fees be made to a "prevailing party ... unless the court finds the position of the United States was substantially justified or that special circumstances make an award unjust." "115 An analysis of both law and fact is required by the court in order to make a "substantially justified" determination. "The court emphasized that while all of these statutes contain a prevailing party requirement, the EAJA differs from the Buckhannon statutes because it creates a statutory presumption that the prevailing party shall be granted attorney's fees and requires the court to make two specific findings."

According to the court, the distinctions between the EAJA and the Buckhannon statutes render the Supreme Court's concerns about the risks associated with endorsing the catalyst theory inapplicable. The EAJA's "substantially justified" requirement "provides a safeguard to ensure that a plaintiff's victory had the necessary legal merit to support an award of attorney's fees." "19 Therefore, the court reasoned, a plaintiff could not be awarded attorney's fees merely on the basis of a nonfrivolous complaint that possesses sufficient merit to withstand a motion to dismiss - the merits of the case must be considered. ${ }^{120}$

Considering the "substantially justified" requirement, the court in Brickwood found that "prevailing party" under the EAJA carries a different meaning than "prevailing party" under the fee-shifting provisions in Buckhannon. ${ }^{121}$ The EAJA's prevailing-party requirement

113 Brickwood, $49 \mathrm{Fed} \mathrm{Cl}$ at 745 .

114 Id.

11528 USC \$ 2412(d)(1)(A) (emphasis added).

116 Brickwood, $49 \mathrm{Fed} \mathrm{Cl}$ at 746 .

117 Id. The court noted that while it had previously employed cases examining other feeshifting statutes in interpreting the EAJA's prevailing party provision, the prevailing construction of such provisions "was consistent with the plain language and legislative history" of the EAJA. Id at 745-46 $\mathrm{n}$ 5. Because Buckhannon's newly established standards conflict with the language and history of the EAJA, the distinctions between the EAJA and other fee-shifting statutes are now important. Id.

118 Id at 746-47.

119 Id at 747.

120 Id at 746. Certain tradeoffs of including or excluding the catalyst theory, according to Scalia's concurrence in Buckhannon, are rewarding phony claims and denying valid ones respectively. Brickwood, $49 \mathrm{Fed} \mathrm{Cl}$ at $747 \mathrm{n}$ 6, citing Buckhannon, 532 US at 618 (Scalia concurring). The Brickwood court explains that under the EAJA, the "substantially justified" requirement reduces this risk of inclusion so that there is little chance of rewarding phony claims; but the risk of exclusion remains. $49 \mathrm{Fed} \mathrm{Cl}$ at $747 \mathrm{n} 6$.

121 Brickwood, $49 \mathrm{Fed} \mathrm{Cl}$ at 744. 
alone cannot establish the merits of a case, because the "substantially justified" requirement directs a special inquiry into the merits. ${ }^{12}$ For that reason, the court stated that the prevailing-party requirement revolves around "whether the plaintiff's lawsuit actually caused the agency to provide the relief the plaintiff requested."123

Finally, the Brickwood court echoed the dissent in Buckhannon by stating that "to interpret Buckhannon as requiring formal written judgments on the merits or formal findings of unlawful conduct will inhibit settlements and discourage parties from taking self-corrective action." ${ }^{124}$ The formal judgment requirement also could result in extended litigation and written opinions in every action, even when a case's merits are obvious. ${ }^{125}$ The court felt that such a view would thwart the purpose of the EAJA: to provide small businesses and individuals with access to the courts "for review of or to defend against unreasonable government action without inhibition."

\section{BUCKHANNON'S DEFINITION OF PREVAILING PARTY SHOULD NOT APPLY TO THE EAJA}

Buckhannon's definition of prevailing party should not apply to the EAJA, and therefore, the catalyst theory should remain viable as a basis for recovery under the EAJA. Several reasons compel this conclusion. First, Buckhannon's holding does not mandate its application to all fee-shifting statutes that authorize an award to prevailing parties. Second, the EAJA is distinguishable based on its language, express private attorneys general rationale, and the presence of the government as a party. Third, legislative purpose indicates that Buckhannon's definition of prevailing party is inconsistent with the EAJA. Fourth, legislative history specifically endorses the catalyst theory as an acceptable means of recovery under the EAJA. Finally, the policy implications of Buckhannon's definition advise against applying that interpretation to the EAJA.

\section{A. The Limited Holding in Buckhannon}

Buckhannon does not demand that the catalyst theory be rejected under the EAJA. Buckhannon specifically limits its holding to

122 Id at 747.

123 Id. The court goes on to say that even if Buckhannon standards were applied to this case, the plaintiff would still be a prevailing party. Id. The court's remarks at the hearing "amounted to a finding that the Navy had acted unlawfully" and "represent the necessary 'judicial imprimatur' that caused the change in the legal relationship of the parties." Id at 749.

124 Id.

125 Id.

126 Id. 
the ADA and the FHAA. ${ }^{127}$ While other fee-shifting statutes are discussed elsewhere in the opinion and the Court notes that it has interpreted fee-shifting provisions consistently, ${ }^{128}$ their mention is dicta. ${ }^{129}$ The opinion explicitly states that its holding applies to the ADA and the FHAA. ${ }^{130}$ Furthermore, despite the list of statutes referenced in the opinion, the EAJA is not mentioned at all in Buckhannon, not even among those statutes named by the majority as being consistent with the ADA and the FHAA. ${ }^{131}$

\section{B. The EAJA is Distinguishable}

1. "Substantially justified" requirement.

The textual differences between the EAJA and ADA/FHAA suggest that Buckhannon's rationale is not applicable to the EAJA..$^{132}$ As discussed in Brickwood, the "substantially justified" prong of the EAJA's statutory definition alleviates the concerns associated with a broad definition that allows the catalyst theory. ${ }^{133}$ It ensures that a party has prevailed on the merits and creates a higher bar for recovery in a way that other fee-shifting statutes do not. In addition, Congress has left a "safety valve" by providing that the court not award fees

127 See Buckhannon, 532 US at 610 ("[W]e hold that the 'catalyst theory' is not a permissible basis for the award of attorney's fees under the FHAA and ADA.") (internal citations omitted); Brickwood, $49 \mathrm{Fed} \mathrm{Cl}$ at 744 (discussing the limited holding in Buckhannon).

128 Some courts have relied on this fact in construing Buckhannon's holding broadly. See Sileikis, 2001 US Dist LEXIS 12737 at *8-9; Former Employees of Motorola, 176 F Supp 2d at 1373; Thayer, 15 Vet App at 211 (2001).

129 See Buckhannon, 532 US at 602-03 \& n 4; Brickwood, $49 \mathrm{Fed} \mathrm{Cl}$ at 744 (deeming the mention of other fee-shifting statutes in Buckhannon dicta).

130 This is not to say that reading fee-shifting statutes with similar language consistently does not make sense-certainly it does. However, the Supreme Court could not have meant that all fee-shifting statutes, even those that are substantially different, must be interpreted consistently. As discussed in Part III.B, the EAJA is markedly different from the statutes in Buckhannon. While it heretofore may not have been necessary to differentiate the EAJA, these dissimilarities warrant a different interpretation of prevailing party than the one adopted in Buckhannon for the ADA and the FHAA.

131 See Buckhannon, 532 US at 602-03 \& n 4; Brickwood, $49 \mathrm{Fed} \mathrm{Cl}$ at 744 (recognizing that the EAJA is not mentioned in Buckhannon).

132 Compare ADA, 42 USC $\$ 12205$ ("In any action or administrative proceeding commenced pursuant to this chapter, the court or agency, in its discretion, may allow the prevailing party, other than the United States, a reasonable attorney's fee, including litigation expenses, and costs."); FHAA, 42 USC \$ 3613(c)(2) ("In a civil action under subsection (a) of this section, the court, in its discretion, may allow the prevailing party, other than the United States, a reasonable attorney's fee and costs."), with EAJA, 28 USC $\$ 2412$ (d)(1)(A) ("[A] court shall award to a prevailing party other than the United States fees and other expenses ... unless the court finds that the position of the United States was substantially justified or that special circumstances make an award unjust."). For a thorough discussion of these differences and the resulting implications, see notes 111-23 and accompanying text.

133 See Brickwood, $49 \mathrm{Fed} \mathrm{Cl}$ at 747 (discussing the effects of the "substantially justified" requirement); see also text accompanying notes 119-20. 
when special circumstances make an award unjust. ${ }^{134}$ Hence, the EAJA's standard for a prevailing party's recovery is substantially different than the ADA and FHAA standard that a court "in its discretion" may award fees..$^{135}$ Because of this difference, Buckhannon's rule does not apply to the EAJA, and a broader definition of prevailing party is appropriate.

2. Private attorneys general rationale.

Other differences between the EAJA and the ADA/FHAA make application of Buckhannon's rule inappropriate. First, the EAJA is a more general statute than the ADA and the FHAA, both of which address specific types of discrimination. ${ }^{136}$ More significantly, the EAJA specifically emphasizes private enforcement as its rationale for fee shifting. ${ }^{137}$ The EAJA was a reaction to the Supreme Court's limitation of fee shifting in Alyeska. ${ }^{138}$ Congress passed the EAJA to preserve and promote private enforcement, and the unprecedented statute was designed to expand fee-shifting authority greatly. ${ }^{139}$ As a result, the EAJA increases government liability for attorney's fees. ${ }^{140}$ These aspects of the EAJA separate it from the ADA and FHDA. A broader definition of prevailing party than Buckhannon's conception is more consistent with the expansion of liability for attorney's fees that Congress sought to achieve under the EAJA.

\section{Government as a party.}

The greatest difference between the EAJA and the ADA/FHAA, and also the most compelling reason for adopting a broader definition, is that the EAJA involves suits brought by or against the government.

134 HR Rep No 96-1418 at 11 (cited in note 28).

13542 USC $\$ 12205 ; 42$ USC $\$ 3613$ (c)(2).

136 On the EAJA, see HR Rep No 96-1418 at 9 (cited in note 28) ("[The EAJA] establish[es] a general statutory exception for an award of fees against the Government."). The EAJA applies in a multitude of litigation contexts, see 28 USC $\$ 2412$ (d)(1)(A) (providing for an award of attorney's fees "in any civil action (other than cases sounding in tort) ... brought by or against the United States"), while the ADA and FHAA are situation-specific. See ADA, 42 USC \$12205 (providing for an award of attorney's fees in cases involving discrimination against qualified individuals with disabilities); FHAA, 42 USC $\S 3613(\mathrm{c})$ (2) (providing for an award of attorney's fees in cases involving discriminatory housing practices).

137 See EAJA $\$ 202(a), 94$ Stat at 2325 ("Congress finds that certain individuals, partinerships, corporations, and labor and other organizations may be deterred from seeking review of, or defending against, unreasonable governmental action because of the expense involved in securing the vindication of their rights in civil actions and in administrative proceedings.").

138 According to Congress, the Supreme Court in Alyeska had "limited the inherent powers of courts to award fees when the prevailing party acted as a private attorney general." HR Rep No $96-1418$ at 6 (cited in note 28).

139 See text accompanying notes $12-20$.

140 HR Rep No 96-1418 at 6-7 (cited in note 28). 
The fact that the government is necessarily the party against whom a citizen is litigating differentiates the EAJA so that a broader definition of prevailing party than Buckhannon's is justified. ${ }^{141}$ Furthermore, because of the government's role, the implications of the Buckhannon rule are more severe than when a private party is involved. The federal government was not a party in Buckhannon, so the following concerns were not present:

a) Disincentive to litigate against the government. There is a greater disincentive to litigate against the government than a private party, so more encouragement of citizen suits is needed. A disparity exists because of government's greater resources and expertise. ${ }^{1 / 2}$ Litigation against the government is intimidating and its size and power discourage suits against it. ${ }^{143}$ Congress tried to level the playing field with the EAJA. ${ }^{14}$ Considering that Congress attempted to counteract this increased deterrence through the EAJA, catalysts should be able to recover attorney's fees from the government as prevailing parties under the EAJA.

141 See EAJA § 202(b), 94 Stat at 2325 ("The Congress further finds that because of the greater resources and expertise of the United States the standard for an award of fees against the United States should be different from the standard governing an award against a private litigant, in certain situations."). The ADA and FHAA do not limit their applicability to suits involving the government. See ADA, 42 USC $\$ \$ 12112(a), 12132,12182$ (a) (prohibiting discrimination by various entities, including employers, employment agencies, labor organizations, joint labor-management committees, public entities, and persons who own, lease (or lease to), or operate a place of public accommodation); FHAA, 42 USC $\$ 3613$ (a)(1)(A) ("An aggrieved person may commence a civil action in an appropriate United States district court or State court not later than 2 years after the occurrence ... to obtain appropriate relief with respect to such discriminatory housing practice or breach.").

142 See EAJA $\S 202(\mathrm{~b}), 94$ Stat at 2325 (noting the greater resources and expertise of the United States); HR Rep No 96-1418 at 5-6 (cited in note 28) ("The economic deterrents to contesting governmental action are magnified in these cases by the disparity between the resources and expertise of these individuals and their government. The purpose of the bill is to reduce the deterrents and disparity."). See also Harold J. Krent, Fee-Shifting Under the Equal Access to Justice Act-A Qualified Success, 11 Yale L \& Pol Rev 458, 463 (1993) (discussing the lack of parity between the government and private noninstitutional litigants, noting in particular that the government "can marshal more resources" and that "the government's sheer size may give it an unfair advantage in litigation").

143 See id at 463 n 24 ("[S]ome private parties plainly cannot afford to litigate in the same style as the government, and they may not pursue litigation against the government vigorously because of their lack of resources.").

144 See HR Rep No 96-1418 at 5-6, 9 (cited in note 28) (discussing the purpose of the EAJA); Haywood, Comment, 61 U Chi L Rev at 990 (cited in note 10) ("The EAJA's stated purpose was to level the playing field for private citizens and businesses, especially those of lesser means, in litigation with the government."). The EAJA leveled the playing field by (1) "ensur[ing] that the United States will be subject to the common law and statutory exceptions to the American Rule regarding attorney fees" and (2) "entitling certain prevailing parties to recover an award of attorney fees, expert witness fees and other expenses against the United States, unless the Government action was substantially justified." HR Rep No 96-1418 at 6 (cited in note 28). 
If Buckhannon's definition is applied to the EAJA, the disincentive to sue the government may be increased because the government could moot cases by voluntarily changing its behavior. The government may be in a better position to change its harmful behavior if it chooses to do so. ${ }^{1.5}$ Moreover, it has a duty to the people and may be more likely to change its conduct when a problem is brought to its attention. Suits against the government may be mooted more than with private parties; if unable to recover in this situation, citizens are even less likely than normal to assert themselves in the first place. Furthermore, when the merits of a case are strong, the government is even more likely to change its behavior. As a result, citizens will be most discouraged from bringing suits when they are needed the most.

b) Check on government. Citizens who vindicate their rights in litigation with the government act as an important check on the government. The impact of unreasonable government action is profound; without the ability of citizens to contest such action, the government can coerce compliance. ${ }^{146}$ Improper behavior by the government must be deterred, and citizen suits are invaluable in this respect. ${ }^{147}$ They function to assure that government actions are working fairly and effectively as well as to hone the system. ${ }^{148}$ In a suit with the government, a citizen not only protects his own interest but refines public policy." With so much at stake when the government is involved, it is extremely important to encourage citizen suits. ${ }^{150}$ Considering the rapid growth of agencies and regulation, an increased need for checks and

145 The government is in a better position because it has greater resources with which to affect change and because its economic cost of change is mitigated by the fact that it is not a profitmaximizing entity. Although the government's bureaucracy tends to slow its action, this is less of a concern, since the litigation process itself is slow. In addition, many of these cases involve agencies, which may be able to react more quickly than the government as a whole.

146 See HR Rep No 96-1418 at 10 (cited in note 28) ("[T]he ability of most citizens to contest any unreasonable exercise of authority has decreased. Thus . . . the Government with its greater resources and expertise can in effect coerce compliance with its position.").

147 See id at 9-10 (discussing the fact that citizens are deterred from litigating against the government, the negative effects this produces, and the benefits that arise when an individual vindicates his rights against the government).

148 See id at 10 (explaining that litigation can uncover error in the underpinnings of a rule and "may provide a vehicle for developing or announcing more precise rules").

149 See id (A litigant "against the Government is not only representing his or her own vested interest but is also refining and formulating public policy. An adjudication or civil action provides a concrete, adversarial test of Government regulation and thereby insures the legitimacy and fairness of the law.").

150 Usually, the appropriate remedy for a citizen wanting to effect change is through the legislature, but Congress has made exceptions to sovereign immunity to allow citizens to address certain issues through resort to the judicial process. By subjecting the government to liability for attorney's fees in certain circumstances, the EAJA creates an exception to sovereign immunity so as to encourage socially beneficial litigation. Sovereign immunity remains an integral part of our legal system in many other contexts. 
balances exists. ${ }^{151}$ Therefore, a broad definition of prevailing party should be maintained.

Once again, the effects of applying Buckhannon's definition are more severe because the government is involved. If catalysts do not recover, then citizens are deterred from contesting unreasonable government actions. With the decreased threat of citizen suits, the government may have less of an incentive to refrain from unreasonable exercises of authority or excessive regulation. This incentive may be lessened further by the reduced cost to the government of any citizen suit that is brought: even if challenged, the government may change its behavior without having to pay attorney's fees. Thus, rejection of the catalyst theory creates a situation in which there is a greater danger of abuse by the government.

c) Compensation for citizens who promote the public welfare. Finally, from a fairness standpoint, citizens should be able to recover from the government as catalysts. The government should not be able to exploit citizens; it is only just to compensate a party that compels the government to take favorable action. Congress recognized the unfairness of expecting a citizen to bear this cost when he is serving a public purpose. ${ }^{122}$ The House Report on the EAJA states, "the expense of correcting error on the part of the Government should not rest wholly on the party whose willingness to litigate ar [sic] adjudicate has helped to define the limits of Federal authority."153 For this additional reason, the catalyst theory should be included under the EAJA and Buckhannon should not be applied.

\section{Legislative Purpose}

A narrow reading of prevailing party frustrates the purpose of the EAJA. Congress enacted the EAJA because it feared that the costs of securing vindication of rights combined with an inability to recover attorney's fees precluded resort to the adjudicatory process for many citizens. ${ }^{144}$ As Congress stated, "[litigants] may be deterred from seeking review of, or defending against, unreasonable governmental action because of the expense involved in securing the vindication of their rights in civil actions." pand the liability of the United States in order to encourage parties to contest injustice. Therefore, it chose a broad standard for recovery,

151 HR Rep No 96-1418 at 9-10 (cited in note 28).

152 See id at 10.

153 Id. Note that the House Report said "the party whose willingness to litigate ... [or] adjudicate" and not "the party whose litigation or adjudication." Id (emphasis added).

154 Id at 5-6 (discussing the "economic deterrents of contesting governmental action").

155 EAJA § 202(a), Pub L No 96-481, 94 Stat 2325 (1980).

156 HR Rep No 96-1418 at 6-7 (cited in note 28). 
one that would "be different from the standard governing an award against a private litigant.",157

Rejection of the catalyst theory is inconsistent with these objectives. It perpetuates the problems the EAJA was designed to ameliorate, because it deters citizens from vindicating their rights. Disallowing recovery under the catalyst theory makes it more difficult for parties to qualify as prevailing; as a consequence, there is less incentive for parties to vindicate their rights. As Justice Ginsburg states, Buckhannon's definition "impede[s] access to court for the less well-heeled, and shrink[s] the incentive Congress created for the enforcement of federal law by private attorneys general." ${ }^{\text {158 }}$ This is precisely the result Congress was trying to avoid. Adoption of Buckhannon's definition of "prevailing party" would frustrate the broad standard Congress enacted. The catalyst theory, on the other hand, furthers the EAJA's goal of serving the public interest and ensuring equal access to the government. Considering the civil rights objectives Congress had in mind when it enacted the EAJA, it is better to err on the side of qualifying too many parties as "prevailing" rather than excluding some who should qualify.

The question of whether to approve the catalyst theory is a matter of degree: how far must the courts go to prevent deterrence? When enacting the EAJA, Congress was so concerned with deterrence that it placed the burden of proof on the government to prove its position was "substantially justified." to reducing deterrence and suggests that a broad interpretation of prevailing party, which would further encourage citizens to vindicate their rights, is congruent with the EAJA.

\section{Legislative History}

Legislative history reveals that Congress intended the catalyst theory to be a means of achieving prevailing-party status under the EAJA. Congress dictated that interpretation of the term "prevailing party" should be "consistent with the law that has developed under existing statutes." At the time of this enactment, the catalyst theory was viewed as an accepted form of recovery. ${ }^{161}$ Moreover, Congress

157 EAJA § 202(b), Pub L No 96-481, 94 Stat 2325.

158 Buckhannon, 532 US at 623 (Ginsburg dissenting).

159 See HR Rep No 96-1418 at 10 (cited in note 28) ("[T]he strong deterrents to contesting government action require that the burden of proof rest with the Government.").

160 Id at 11.

161 See, for example, Nadeau v Helgemoe, 581 F2d 275, 279 (1st Cir 1978) ("It is often explained that when plaintiff's lawsuit acts as a 'catalyst' in prompting defendants to take action to meet plaintiff's claims, attorney's fees are justified despite the lack of judicial involvement in the result."); Ross v Horn, 598 F2d 1312, 1322 (3d Cir 1979) (looking to the substance of the litigation's outcome). 
specifically stated that "sprevailing party' should not be limited to a victor only after entry of a final judgment following a full trial on the merits." vailing if he obtains a favorable settlement of his case, ${ }^{1163}$ citing Foster $v$ Boorstin. ${ }^{164}$ The court in Foster held that the effectiveness of the feeshifting provision would be greatly reduced if the government could avoid liability for fees simply by awarding the requested relief after a court action had been filed but before a judgment or court order. ${ }^{165}$ Considering its endorsement of this case and other clarifying remarks, Congress clearly intended to include catalysts as prevailing parties. ${ }^{16}$ While other fee-shifting statutes may be ambiguous on this issue, as the Supreme Court has found, Congress's explicit direction disqualifies any conflicting notion of prevailing party under the EAJA. ${ }^{\text {167 }}$

One last detail of the House Report is notable, in part because courts have relied upon consistency of interpretation among feeshifting statutes in applying Buckhannon to the EAJA. While interpretation of prevailing party under the EAJA was directed to be consistent with the law that had developed under other statutes, that consistency was to be with law that had developed, not law that would develop. Congress specifically mentioned the law to which it was referring. ${ }^{163}$ Though that law might have changed now, the law that Congress approved remains that which was in existence at the time Congress wrote the statute.

162 HR Rep No 96-1418 at 11 (cited in note 28).

163 Id.

$164561 \mathrm{~F} 2 \mathrm{~d} 340$ (DC Cir 1977), cited in HR Rep No 96-1418 at 11 (cited in note 28).

165 See Foster, 561 F2d at 342-43. Foster awarded attorney's fees to a catalyst who had received the relief he sought after the filing of and as a result of a lawsuit. Id at 341 . No judicial relief was granted, aside from the receipt of the complaint and a stay of the proceedings by consent of the parties. Id at 341-42. The Foster court felt the catalyst theory was consistent with the incentive Congress was trying to create for persons of limited means. Id at 342-43.

166 See HR Rep No 96-1418 at 11 (cited in note 28) (discussing prevailing party); see also Photo Data, Inc v Sawyer, 533 F Supp 348, 351 (D DC 1982) (relying on the legislative history of the EAJA in awarding attorney's fees to a party who obtained a favorable settlement of his case).

167 The Buckhannon majority found the legislative history in that case "at best ambiguous." 532 US at 607-08. See notes $47-48$ and accompanying text. The legislative history of the EAJA is not ambiguous. While some of the language is similar to the language in the legislative history materials in Buckhannon, the case referenced in the House Report to the EAJA clearly embraces the catalyst theory and involves no enforceable judgment, unlike the case referenced in the legislative materials in Buckhannon. See note 48.

168 See HR Rep No 96-1418 at 11 (cited in note 28) (citing, among others, Foster, 561 F2d 340; Bradley v School Broad of the City of Richmond, 416 US 696 (1974); Corcoran v Columbia Broadcasting System, Inc, 121 F2d 575 (9th Cir 1941)).

169 Even if the interpretation of prevailing party were to have been consistent with the law that would develop under existing statutes instead of the law that had developed, Buckhannon would not apply, because the ADA and FHAA were not "existing statutes" at the time the EAJA was enacted. The statutes in Buckhannon were not enacted until 1990 and 1988 respectively, so they do not fall within the body of law which Congress specified should be consistent 


\section{E. Consequences of Buckhannon's Definition}

Finally, there are four policy and incentive reasons why Buckhannon's definition should not apply to the EAJA. Two already have been mentioned, namely that a definition of prevailing party excluding the catalyst theory would deter "meritorious but expensive suits" would create an incentive for defendants to moot cases before judgment to avoid attorney's fees. ${ }^{171}$ Third, Buckhannon's rule likely would discourage informal settlement and increase litigation, which is inefficient. ${ }^{12}$ Instead of settling a case out of court with its opponent, a party may be compelled to continue with litigation-consuming judicial resources and increasing costs-in order to recover attorney's fees. Fourth, rejection of the catalyst theory creates a disincentive for attorneys who would pursue public interest cases. ${ }^{173}$ Fee shifting has been used to encourage and allow attorneys to undertake complex civil rights and environmental cases when plaintiffs otherwise would be unable to afford to pay them. ${ }^{174}$ Under the Buckhannon rule, attorneys may be deterred by the possibility of not recovering fees even when the plaintiff receives the requested relief. This problem is compounded by the increased incentive that defendants have to moot a case unilaterally at the last minute in order to avoid attorney's fees. ${ }^{175}$

Several potential policy concerns about applying the catalyst theory under the EAJA warrant discussion. First, a broader definition of prevailing party would increase litigation, since the ability to recover as catalysts removes deterrents to litigation. Whatever hesitation is associated with encouraging more suits, increased litigation is justified in this situation by the important societal value of these suits. Similarly, secondary litigation could arise if courts must determine whether a party has been a catalyst. ${ }^{176}$ While courts undoubtedly will have to de-

with the EAJA.

170 Buckhannon, 532 US at 608.

171 See Part III.B.3.a and text accompanying note 50.

172 See Thomas Scarlett, Supreme Court Limits Reimbursement of Attorney Fees under Federal Statutes, Trial 16 (Aug 2001) (noting the irony of a decision which may "force some claimants into litigation rather than allow an informal settlement").

173 See Marcia Coyle, Fee Change is a Sea-Change; But Some Seek Way to Skirt Justices' Limit on Catalyst Theory Fees, Natl L J A1 (Jun 11, 2001) (commenting that the fee-shifting provisions were tools employed by Congress to inspire attorneys to handle complex environmental and civil rights cases and discussing the negative impact Buckhannon will have on litigation under the fee-shifting statutes).

174 See id.

175 See Baumgartner v Harrisburg Housing Authority, 21 F3d 541, 548 (3d Cir 1994) ("[I]f defendants could deprive plaintiffs of attorney's fees by unilaterally mooting the underlying case by conceding to plaintiffs' demands, attorneys might be more hesitant about bringing these civil rights suits.").

176 Chief Justice Rehnquist raises this concern in Buckhannon, 532 US at 609-10. See also note 52 and accompanying text. 
cide whether a party qualifies as a catalyst if it is to recover under that theory as a prevailing party, it may be worth the cost in order to stimulate private enforcement of public policy and enable those with "meritorious but expensive" suits to have access to the courts." These are the laudable goals of the EAJA. Nonetheless, the catalyst determination is no different than the numerous other determinations that a court makes on a regular basis. ${ }^{173}$ Specific guidelines are in place for making such a determination and have been used by the courts of appeals for years. Perhaps most importantly, this extra litigation must be balanced with the corresponding decrease in litigation that results from allowing the catalyst theory. If catalysts can recover, parties are not forced to keep litigating in order to receive the mandated judicial stamp of approval, as they would under the rule in Buckhannon. Litigation may be discontinued earlier, when the government grants relief, and judicial resources saved. ${ }^{17}$

Another concern associated with adopting the catalyst theory is the disincentive that may be created for a defendant to change its conduct voluntarily. ${ }^{180}$ This concern is lessened under the EAJA because the defendant is not a private party. The government is less likely to be disincentivized since it has no profit-maximizing motive; it also has great financial resources. In addition, even though the government may be liable for fees if it changes its conduct, it still may decide that changing its conduct earlier offsets the cost of continued litigation, potential damages, and the potential cost of even higher attorney's fees later. Allowing catalysts to recover also may create an incentive for the government ex ante to ensure that its behavior is beyond reproach, because changing its conduct after litigation has begun would be costly.

\section{CONCLUSION}

An analysis of the language and structure of the relevant cases and statutes, principles of legal interpretation, Congress's purpose and intent, and various policy and incentive concerns reveals that Buckhannon's interpretation of prevailing party does not and should not apply to the EAJA. The Buckhannon opinion is limited to the ADA and the FHAA, and furthermore, the EAJA is distinct from those

177 Buckhannon, 532 US at 608.

178 Baumgartner, 21 F3d at 548 (describing the question in a catalyst case as one "of degree and one which the district courts, in their factfinding expertise, deal with on a regular basis").

179 Buckhannon, 532 US at 639-40 (Ginsburg dissenting) (arguing that the catalyst rule preserves judicial resources).

180 Id at 608. See also text accompanying note 51 .

181 Buckhannon, 532 US at 639 (Ginsburg dissenting) (discussing the incentives that the catalyst theory has on compliance with the law). 
statutes such that Buckhannon does not apply. The EAJA's "substantially justified" requirement, recognized private attorneys general rationale, and its requirement that the government be a party distinguish the statute. In addition, Buckhannon should not be applied because its rule is inconsistent with the EAJA's purpose and because legislative history shows that Congress intended the catalyst theory to be a means of achieving prevailing-party status. Extension of Buckhannon to the EAJA would enfeeble a statute which was expressly designed to expand statutory fee shifting in the hopes of stimulating private enforcement. Policy and incentive implications of a narrow definition of prevailing party also cut against extending Buckhannon to the EAJA. Therefore, even in the wake of Buckhannon, the catalyst theory should remain viable under the EAJA. 